\title{
Tap Water Quality Degradation in an Intermittent Water Supply Area
}

\author{
Bijay Man Shakya • Takashi Nakamura $\mathbb{D} \cdot$ \\ Sadhana Shrestha $\cdot$ Sarad Pathak $\cdot$ Kei Nishida $\cdot$ \\ Rabin Malla
}

Received: 8 September 2021 / Accepted: 22 December 2021 / Published online: 25 February 2022

(C) The Author(s) 2022

\begin{abstract}
Decentralized tap water systems are an important drinking water source worldwide. A good quality, high-pressure continuous water supply (CWS) is always the target of any urban settlement. However, tap water in some areas are reported with deteriorated water quality even though treated well before supplying. Such deterioration of tap water quality is reported widely from areas with low water availability and in economically poor countries where water are supplied intermittently (IWS). This study focuses in identifying tap water quality in IWS and causes of water quality degradation using nitratenitrogen $\left(\mathrm{NO}_{3}-\mathrm{N}\right)$ as an indicator and stable isotopes of hydrogen $(\delta D)$ as tracer. Nine water reservoirs and ninety municipal tap water (ten per reservoir) samples were collected during the wet (June-September)
\end{abstract}

B. M. Shakya $\cdot$ S. Shrestha $\cdot$ S. Pathak $\cdot$ R. Malla $(\square)$ Center of Research for Environment, Energy and Water, Baluwatar, Kathmandu-4, Nepal

e-mail: rabin@creew.org.np

B. M. Shakya $\cdot$ T. Nakamura $(\bowtie) \cdot K$. Nishida Interdisciplinary Centre for River Basin Environment, University of Yamanashi, Kofu 400-8511, Japan

e-mail: t.nakamaru@yamanashi.ac.jp

S. Shrestha

United Nation University-Institute for the Advanced Study of Sustainability, Shibuya, Tokyo 150-8925, Japan

S. Shrestha

Institute for Future Initiatives (IFI), The University

of Tokyo, 7-3-1 Bunkyo, Tokyo 113-8654, Japan and dry (November-February) seasons in the Kathmandu Valley (KV), Nepal. Ten percent of the tap water samples exhibited higher $\mathrm{NO}_{3}-\mathrm{N}$ than those of their respective reservoirs during the wet season, while $16 \%$ exhibited higher concentrations during the dry season. Similarly, the isotopic signatures of tap water exhibited $3 \%$ and $23 \%$ higher concentrations than those of their respective reservoirs during the wet and dry seasons, respectively. Coupling analysis between $\mathrm{NO}_{3}-\mathrm{N}$ and $\delta \mathrm{D}$ demonstrates close connection of groundwater and tap water. The results indicate groundwater intrusion as the primary component in controlling tap water quality variations within the same distribution networks during IWS. Meanwhile, the obtained results also indicate probable areas of intrusion in the $\mathrm{KV}$ as well as usefulness of $\delta \mathrm{D}$ as a tool in the assessment of tap water systems.

Keywords Tap water contamination - Intermittent water supply · Low pressurized tap · Groundwater intrusion · Developing country $\cdot$ Kathmandu Valley

\section{Introduction}

Maintaining safe drinking water for growing populations is a major global issue. In addition, anthropogenic impacts on water sources and climate change have raised serious concerns regarding drinking water resources (IPCC, 2008). The construction of continuously available and easily accessible water sources, 
their maintenance, and sustainability are continually being developed to cope with drinking water scarcity. Therefore, decentralized municipal tap water systems have served as a critical component of safe and convenient drinkable water (Howard \& Bartram, 2003).

Although municipal tap water networks are safe, they are vulnerable to artificial (pressure loads, management, and replacement) and natural changes (underground stresses, earthquakes, disasters) that can cause dislocations and ruptures (Chandra et al., 2016; Wols et al., 2014). Losses of 5-35\% of water (Lambert et al., 2014) through ruptures in municipal tap water networks are inevitable which can reach up to $50 \%$ in low-income countries (Dudley \& Stolton, 2003). These ruptures and losses have a significant effect of water leakage faced by areas with continuous water supply (CWS) (24 h) wherein the water supply is steadily under high pressure. On the other hand, intermittent water supply (IWS) strategy with limited supply per day $(<24 \mathrm{~h})$ to per week $(1-3 \mathrm{~h}$ in a week) has been adopted as a counter measure to cope with water shortages and losses in economically poor countries (van den Berg \& Danilenko, 2011; WHO \& UNICEF, 2000). However, chemical and microbiological contamination has been found to be significantly higher during IWS than during CWS (Erickson et al., 2017; Kumpel \& Nelson, 2014).

Previous studies have reported that contamination of the tap water distribution network-harbored material (DNHM) is caused by chemical disintegration and microbiological re-growth (Liu et al., 2017). Disintegration and re-growth are even higher in IWS settings during periods of no supply (Coelho et al., 2003). In addition, the occurrence of transient low or negative pressure mechanisms in the distribution pipes during IWS is ubiquitous during transport (Fontanazza et al., 2015; Kumpel \& Nelson, 2014; van den Berg \& Danilenko, 2011). Presence of any ruptures in the distribution network thus acts as a major gateway for subsurface backflow and foreign water intrusions. These intrusions ultimately contribute to the degradation and contamination of drinking water quality, which is also related to the surrounding groundwater conditions (Grimmeisen et al., 2016). Groundwater, which is in close contact with municipal drinking water pipes, is reported to be contaminated with both chemical and microbiological contaminants, especially in developing countries
(Nakamura et al., 2012; Shakya et al., 2019b; Shrestha et al., 2014; Umezawa et al., 2009), resulting in a higher likelihood of the deterioration of tap water quality caused by backflow into pipe network. Any changes in the tap water quality compared with reservoirs and nearby contaminated groundwater might indicate the tap water quality variations within the same network. Since $\mathrm{NO}_{3}-\mathrm{N}$ in groundwater is considered an indicator of contaminations, studies focusing on determination of the tap water quality especially from $\mathrm{NO}_{3}-\mathrm{N}$ create a concept on the drinking water situation and its possible risk (Schullehner et al., 2018). However, chemical and microbial tracers alone may not be reliable for defining tap water degradation, whether it is from the DNHM or intrusions. Meanwhile, the use of oxygen $\left(\delta^{18} \mathrm{O}-\mathrm{H}_{2} \mathrm{O}\right)$ and hydrogen $(\delta \mathrm{D})$ isotopes in water has been advantageous for identifying various types of mixing in diverse hydrological studies (Craig, 1961; Gonfiantini et al., 1998). The fractionation of the isotopic signatures $\left(\delta \mathrm{D}\right.$ and $\left.\delta^{18} \mathrm{O}-\mathrm{H}_{2} \mathrm{O}\right)$ of water caused by natural processes (evaporation or condensation) is identical and can be identified. The distinct isotopic values of various water sources, as well as the properties of the isotopic tracers, have aided a wide variety of mixing studies and have been used advantageously for hydrological studies (Nakamura et al., 2016; Yang et al., 2012). Additionally, stable isotopes especially $\delta \mathrm{D}$ is unaffected by the pre-treatment processes. With all the advantages, stable isotopes have been used to determine the water dynamics in urban areas with CWS (Bowen et al., 2007; de Wet et al., 2020; Ehleringer et al., 2016; Jameel et al., 2018; Tipple et al., 2017; Zhao et al., 2017). As CWS does not experience foreign intrusions (Erickson et al., 2017), the dependency on isotopic signatures for tap water conditions and dynamics in an IWS setting presents challenges. Thus, the isotopic signatures coupled with chemical parameters among the water sources might be beneficial for understanding and investigating municipal tap water chemical contamination in urban areas facing IWS.

In this study, we investigated the municipal drinking water system of the Kathmandu Valley (KV) in Nepal. Similar to other cities in South Asia facing IWS (including Delhi, Dhaka, and Karachi), the KV faces higher intermittent supplies of all drinking 
water systems (McIntosh, 2003). Most of the residents in the KV experience an IWS for 2-4 h/week (Shrestha et al., 2017). More specifically, they experience intermittent supplies three or fewer times per week for two or fewer hour each time (Guragai et al., 2017). Despite better access to drinking water than in rural areas of Nepal, people in the KV experience safe drinking water problems in terms of both quality and quantity (Koju et al., 2015; Thapa et al., 2017, 2019; Udmale et al., 2016; Warner et al., 2008). Furthermore, the study area is often reported with the aging distribution network pipes and management (KUKL, 2019). The coupled use of $\mathrm{NO}_{3}-\mathrm{N}$ as an indicator of contamination and isotopic signatures in areas severely affected by water shortages and intermittent distribution presents a new perspective on the diversity of tap water chemical contamination status in urban areas. Therefore, we highlighted the seasonal tap water $\mathrm{NO}_{3}-\mathrm{N}$ contamination, its possible causes in the KV IWS, and the use of isotopic signatures as a tool in tracking the area of contamination from the distribution reservoir to the end users in the urban area.

\section{Materials and Methods}

\subsection{Study Area}

The KV is located in the foothills of the Himalayas and is an isolated closed intermountain basin. The basin extends from $27^{\circ} 32^{\prime} 34^{\prime \prime}$ to $27^{\circ} 49^{\prime} 11^{\prime \prime} \mathrm{N}$ and from $85^{\circ} 11^{\prime} 10^{\prime \prime}$ to $85^{\circ} 31^{\prime} 10^{\prime \prime} \mathrm{E}$ (Fig. 1). The valley covers an area of $664 \mathrm{~km}^{2}$, with elevations ranging from 1212 to $2722 \mathrm{~m}$ above sea level. The water resources in the valley are rainfall-dependent. The

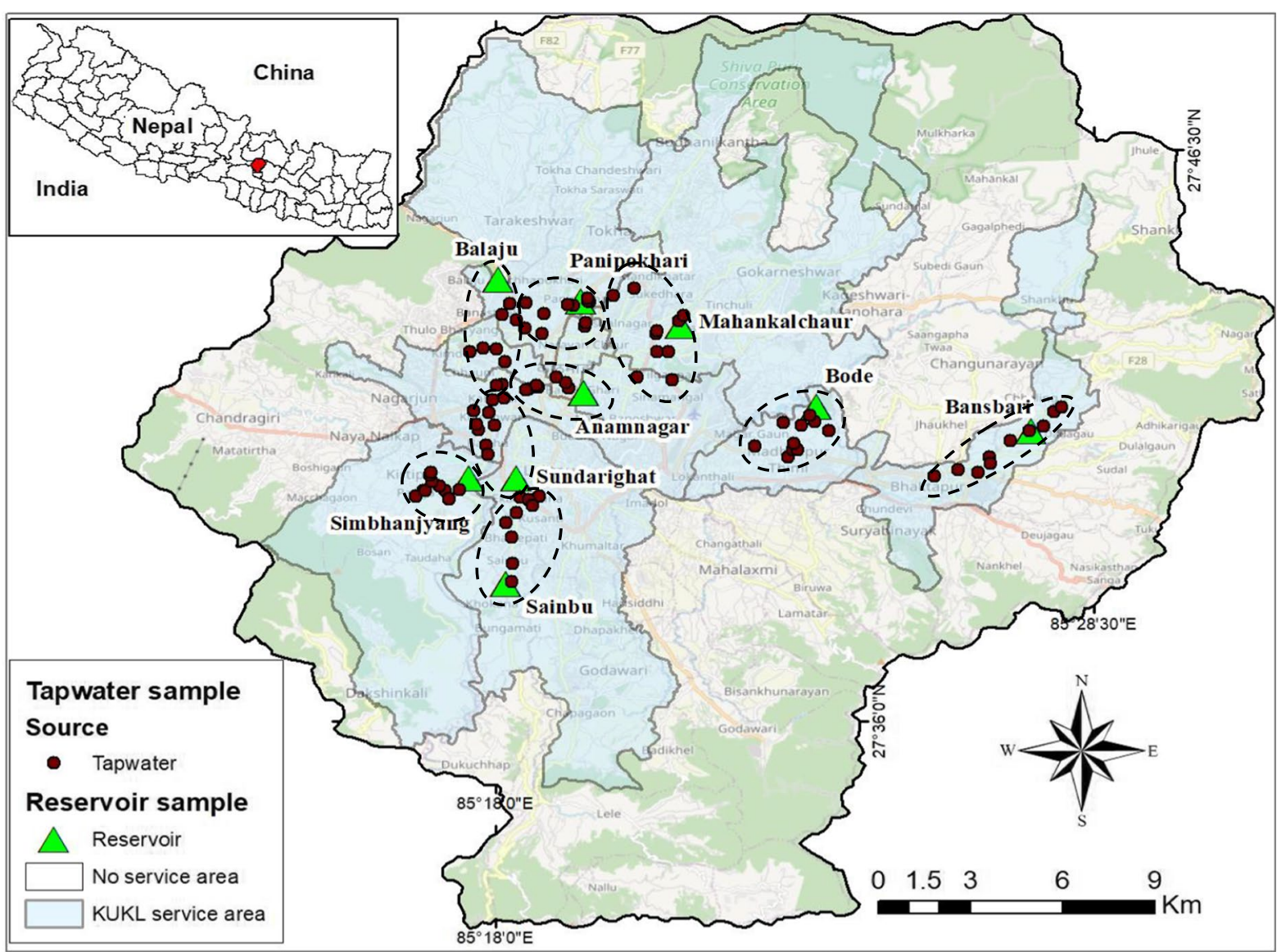

Fig. 1 Geographical boundary of the Kathmandu (KTM) Valley, with KUKL service areas shown in blue. Areas outside of the blue highlighted regions are not serviced by KUKL. The dashed line represents tap water from their respective reservoirs 
KV receives $80 \%$ of its annual rainfall during the monsoon (wet) season (June-September), 14\% during the pre-monsoon season (March-May), and 6\% during the dry season (November-February) (Prajapati et al., 2021).

The sole water supply utility, Kathmandu Upatyaka Khanepani Limited (KUKL), has difficulties covering the annual drinking water demand for a population of 2.5 million people. According to KUKL (2021), the total demand for drinking water in 2019 reached 470 million liters per day (MLD); however, the provider was only able to provide 120 MLD during the wet season and 108 MLD during the dry season. The water supply demand is managed by a long intermittent supply, while the deficits are covered by groundwater supplies and other water vendors. Deep groundwater extracted from spatially distributed aquifers reaching the depths of 75-300 m is used for the drinking water supply by KUKL, while shallow groundwater at depths of up to $50 \mathrm{~m}$ is commonly used for local water use.

\subsection{Tap Water and Reservoir Sample Collection}

In this study, 198 samples were collected from around the KV during 2018-2019 (Fig. 1). Spatially distributed treated drinking water reservoirs in nine service areas, as well as 10 successive municipal taps (at the consumer end) within $3-5 \mathrm{~km}$ of the reservoir, were sampled during two consecutive seasons, i.e., wet (June-September 2018) and dry (November 2018-February 2019). Ninety-nine samples were collected per season. Tap water samples were collected 5-10 min after the supply started during the intermittent cycle. In case of reservoirs, samples were collected from the storage tanks. The samples were collected in $120 \mathrm{ml}$ airtight high-density polyvinyl chloride (PVC) bottles. The samples were transferred from the collection area stored in a cooler bag with no preservatives added, then stored at $-4{ }^{\circ} \mathrm{C}$. The samples were then transferred to the Interdisciplinary Centre for River Basin Environment at the University of Yamanashi (ICRE-UY) in Japan for further analysis.

The groundwater data used for comparison with the tap water data were adopted from the data previously reported by Shakya et al., (2019a, b).

\subsection{Laboratory Analyses}

The hydrogen $(\mathrm{H})$ and oxygen $(\mathrm{O})$ stable isotopic compositions and the chemical parameters of the samples were analyzed in the laboratory at ICREUY. The dual isotopic signatures were analyzed using cavity ring-down spectroscopy (L1102-i, Picarro, Santa Clara, CA, USA). The abbreviations $\delta \mathrm{D}$ and $\delta^{18} \mathrm{O}-\mathrm{H}_{2} \mathrm{O}$ relative to Vienna Standard Mean Ocean Water (V-SMOW) are used to represent the stable isotopes of hydrogen and oxygen in water, respectively. All isotopic ratios are expressed in per mil format (\%o), as shown in Eq. 1:

$\delta^{\mathrm{N}} \mathrm{E}=\left(\frac{R_{\text {sample }}-R_{V-S M O V}}{R_{V-S M O V}}\right) \times 1000(\% \mathrm{o})$

where $N$ is the atomic mass of the heavy isotope of the element, and $E$ and $R$ are the ratios of the heavy to light isotopes $\left({ }^{2} \mathrm{H} /{ }^{1} \mathrm{H}\right.$ or $\left.{ }^{18} \mathrm{O} /{ }^{16} \mathrm{O}\right)$. The measured analytical error of the equipment was $0.5 \%$ ofor $\delta \mathrm{D}$ and $0.1 \%$ o for $\delta^{18} \mathrm{O}-\mathrm{H}_{2} \mathrm{O}$.

The elemental concentrations of the samples $\left(\mathrm{NO}_{3}-\mathrm{N}\right)$ were measured using ion chromatography (ICS-1100, Dionex, USA), with an analytical error of $5 \%$.

\subsection{Statistical Analyses}

Mapping of the analyzed isotopic signatures and chemical parameters was performed using ArcMap version 10.3.1 (Esri Inc., USA). A paired $t$-test was performed to identify the temporal variations among the samples-based on $p$-value of 0.05-using the Statistical Package for Social Studies version 20 (SPSS Inc., Chicago, IL, USA).

\section{Results and Discussion}

Tables 1 and 2 list the statistics of the $\mathrm{NO}_{3}-\mathrm{N}$ concentrations and stable isotopic signatures of the water samples ( $\delta \mathrm{D}$ and $\delta^{18} \mathrm{O}-\mathrm{H}_{2} \mathrm{O}$ ) obtained from the drinking water reservoirs and tap water in the $\mathrm{KV}$, respectively. 
Table 1 Isotopic signatures and hydrochemical data for the tap water samples (isotopic values in $\%$ ond $\mathrm{NO}_{3}-\mathrm{N}$ in $\mathrm{mg} \mathrm{N} / \mathrm{L}$ )

\begin{tabular}{|c|c|c|c|c|c|c|c|c|c|}
\hline \multirow[t]{2}{*}{ ID } & \multirow[t]{2}{*}{ Associated supply reservoir } & \multirow[t]{2}{*}{ Northing } & \multirow[t]{2}{*}{ Easting } & \multicolumn{3}{|l|}{ Wet } & \multicolumn{3}{|l|}{ Dry } \\
\hline & & & & $\delta^{18} \mathrm{O}-\mathrm{H}_{2} \mathrm{O}$ & $\delta \mathrm{D}$ & $\mathrm{NO}_{3}-\mathrm{N}$ & $\delta^{18} \mathrm{O}-\mathrm{H}_{2} \mathrm{O}$ & $\delta \mathrm{D}$ & $\mathrm{NO}_{3}-\mathrm{N}$ \\
\hline KIA 1 & Anamnagar & 27.70295 & 85.302 & -8.71 & -58.00 & 0.20 & -8.12 & -53.80 & 0.11 \\
\hline KIA 2 & & 27.70139 & 85.30897 & -8.74 & -57.33 & 0.14 & -8.24 & -55.70 & 0.20 \\
\hline KIA 3 & & 27.70216 & 85.31252 & -8.54 & -56.02 & 0.17 & -7.91 & -51.10 & 0.13 \\
\hline KIA 4 & & 27.70168 & 85.30985 & -8.60 & -57.21 & 0.19 & -8.06 & -52.80 & 0.04 \\
\hline KIA 5 & & 27.70278 & 85.31195 & -8.65 & -56.58 & 0.21 & -8.37 & -55.80 & 0.01 \\
\hline KIA 6 & & 27.70121 & 85.30886 & -8.75 & -57.35 & 0.22 & -8.55 & -57.50 & n.d \\
\hline KIA 7 & & 27.70355 & 85.32065 & -8.73 & -57.61 & 0.17 & -7.92 & -51.10 & 0.60 \\
\hline KIA 8 & & 27.70189 & 85.32143 & -8.63 & -56.45 & 0.16 & -7.49 & -47.90 & 0.44 \\
\hline KIA 10 & & 27.70523 & 85.31795 & -8.63 & -56.77 & 0.09 & -8.06 & -53.50 & 0.03 \\
\hline KIA 11 & Sainbu & 27.64276 & 85.30469 & -8.95 & -59.12 & 0.43 & -8.84 & -61.00 & 0.38 \\
\hline KIA 12 & & 27.64812 & 85.30511 & -8.87 & -59.13 & 0.06 & -8.96 & -61.10 & 0.36 \\
\hline KIA 13 & & 27.65639 & 85.30482 & -8.95 & -59.30 & 0.31 & -8.24 & -56.90 & 0.92 \\
\hline KIA 14 & & 27.66383 & 85.30613 & -8.96 & -59.34 & 0.41 & -9.10 & -62.80 & 0.09 \\
\hline KIA 15 & & 27.66894 & 85.31294 & -8.92 & -59.60 & 0.42 & -9.20 & -62.50 & 0.32 \\
\hline KIA 16 & & 27.66839 & 85.30719 & -8.81 & -58.88 & 0.57 & -8.77 & -58.50 & 0.25 \\
\hline KIA 17 & & 27.6676 & 85.30968 & -8.90 & -59.28 & 0.45 & -9.07 & -61.20 & 0.24 \\
\hline KIA 18 & & 27.66608 & 85.31083 & -8.96 & -59.72 & 0.46 & -8.23 & -56.80 & 1.25 \\
\hline KIA 19 & & 27.66082 & 85.30314 & -8.98 & -59.46 & 0.45 & -8.29 & -57.50 & 1.88 \\
\hline KIA 20 & & 27.66823 & 85.30356 & -9.01 & -59.14 & 0.45 & -9.09 & -62.30 & 0.13 \\
\hline KIA 21 & Mahankalchaur (Mhchaur.) & 27.7225 & 85.35361 & -8.59 & -55.33 & 0.17 & -8.36 & -55.50 & 0.11 \\
\hline KIA 22 & & 27.72417 & 85.355 & -8.71 & -56.41 & 0.17 & -8.11 & -52.90 & 0.12 \\
\hline KIA 23 & & 27.71861 & 85.34694 & -8.73 & -56.25 & 0.13 & -8.43 & -57.70 & 0.06 \\
\hline KIA 24 & & 27.71306 & 85.35056 & -8.68 & -56.44 & 0.19 & -8.42 & -55.70 & 0.06 \\
\hline KIA 25 & & 27.71944 & 85.34722 & -8.73 & -56.09 & 0.17 & -7.97 & -50.90 & 0.12 \\
\hline KIA 26 & & 27.70528 & 85.34139 & -8.79 & -56.79 & 0.15 & -8.34 & -56.10 & 0.11 \\
\hline KIA 27 & & 27.70444 & 85.35167 & -8.79 & -56.59 & 0.18 & -8.41 & -55.90 & 0.04 \\
\hline KIA 28 & & 27.71306 & 85.34722 & -8.66 & -56.06 & 0.18 & -8.12 & -54.30 & n.d \\
\hline KIA 29 & & 27.7325 & 85.34056 & -8.82 & -56.81 & 0.22 & -8.58 & -58.90 & 0.17 \\
\hline KIA 30 & & 27.73011 & 85.33452 & -8.78 & -56.49 & 0.14 & -8.34 & -56.20 & n.d \\
\hline KIA 32 & Bode & 27.69167 & 85.39333 & -9.23 & -64.05 & 0.33 & -9.26 & -67.30 & 0.13 \\
\hline KIA 33 & & 27.69361 & 85.39194 & -9.45 & -66.23 & 0.24 & -9.33 & -67.30 & n.d \\
\hline KIA 34 & & 27.68417 & 85.37583 & -9.38 & -65.47 & 0.49 & -9.13 & -67.00 & 0.29 \\
\hline KIA 35 & & 27.69056 & 85.38944 & -9.28 & -64.54 & 0.24 & -9.30 & -66.70 & 0.24 \\
\hline KIA 36 & & 27.69139 & 85.38417 & -9.36 & -65.38 & 2.15 & -9.21 & -67.00 & 1.25 \\
\hline KIA 37 & & 27.68306 & 85.38694 & -9.42 & -65.69 & 0.18 & -9.38 & -66.40 & 0.17 \\
\hline KIA 38 & & 27.68306 & 85.38833 & -9.47 & -66.26 & 0.39 & -9.25 & -67.20 & 0.66 \\
\hline KIA 39 & & 27.68889 & 85.3975 & -9.19 & -64.53 & 0.05 & -9.13 & -66.50 & n.d \\
\hline
\end{tabular}


Table 1 (continued)

\begin{tabular}{|c|c|c|c|c|c|c|c|c|c|}
\hline \multirow[t]{2}{*}{ ID } & \multirow[t]{2}{*}{ Associated supply reservoir } & \multirow[t]{2}{*}{ Northing } & \multirow[t]{2}{*}{ Easting } & \multicolumn{3}{|l|}{ Wet } & \multicolumn{3}{|l|}{ Dry } \\
\hline & & & & $\delta^{18} \mathrm{O}-\mathrm{H}_{2} \mathrm{O}$ & $\delta \mathrm{D}$ & $\mathrm{NO}_{3}-\mathrm{N}$ & $\delta^{18} \mathrm{O}-\mathrm{H}_{2} \mathrm{O}$ & $\delta \mathrm{D}$ & $\mathrm{NO}_{3}-\mathrm{N}$ \\
\hline KIA 41 & Sundarighat (Sdghat.) & 27.68444 & 85.29722 & -8.92 & -59.84 & 0.55 & -8.92 & -63.90 & 0.27 \\
\hline KIA 42 & & 27.68167 & 85.29778 & -8.76 & -58.00 & 0.54 & -8.65 & -60.10 & 0.21 \\
\hline KIA 43 & & 27.69056 & 85.29972 & -8.77 & -58.47 & 1.12 & -8.90 & -63.00 & 0.33 \\
\hline KIA 44 & & 27.68917 & 85.295 & -8.16 & -55.34 & 4.20 & -8.63 & -61.10 & 0.81 \\
\hline KIA 45 & & 27.69444 & 85.29806 & -8.88 & -59.45 & 0.49 & -8.90 & -62.00 & 0.31 \\
\hline KIA 46 & & 27.69833 & 85.29917 & -8.93 & -60.60 & 0.72 & -9.03 & -64.00 & 0.29 \\
\hline KIA 47 & & 27.695 & 85.29361 & -8.80 & -59.45 & 0.36 & -8.69 & -61.60 & 0.49 \\
\hline KIA 49 & & 27.69889 & 85.3025 & -8.69 & -58.75 & 0.54 & -8.76 & -61.50 & 0.46 \\
\hline KIA 50 & & 27.70278 & 85.30028 & -8.76 & -58.70 & 0.43 & -8.98 & -63.80 & 0.22 \\
\hline KIA 51 & Balaju & 27.71306 & 85.2925 & -8.91 & -59.61 & 0.40 & -8.87 & -62.20 & 0.61 \\
\hline KIA 52 & & 27.71417 & 85.29639 & -8.74 & -56.60 & 0.11 & -8.47 & -57.10 & 0.16 \\
\hline KIA 53 & & 27.71389 & 85.30028 & -8.78 & -56.24 & 0.14 & -8.47 & -56.80 & 0.24 \\
\hline KIA 54 & & 27.71 & 85.30278 & -8.90 & -58.81 & 0.14 & -7.34 & -51.00 & 1.07 \\
\hline KIA 55 & & 27.72444 & 85.30194 & -8.86 & -57.44 & 0.14 & -8.54 & -57.50 & n.d \\
\hline KIA 56 & & 27.72 & $85 ., 2975$ & -8.83 & -57.52 & 0.15 & -8.03 & -53.40 & 0.28 \\
\hline KIA 57 & & 27.72806 & 85.30889 & -8.81 & -57.24 & 0.13 & -8.11 & -52.80 & 0.23 \\
\hline KIA 58 & & 27.72778 & 85.30417 & -8.96 & -57.48 & 0.14 & -8.31 & -56.60 & 0.04 \\
\hline KIA 59 & & 27.72028 & 85.30861 & -8.84 & -57.24 & 0.13 & -8.36 & -56.70 & 0.18 \\
\hline KIA 60 & & 27.72278 & 85.30611 & -8.79 & -57.03 & n.d & -8.42 & -56.30 & 0.17 \\
\hline KIA 61 & Panipokhari (Panipok.) & 27.72893 & 85.32725 & -8.99 & -60.18 & 2.28 & -8.22 & -53.20 & 1.07 \\
\hline KIA 62 & & 27.72814 & 85.32767 & -8.33 & -59.23 & 8.11 & -8.75 & -59.80 & 0.74 \\
\hline KIA 63 & & 27.7284 & 85.327 & -8.66 & -60.18 & 2.88 & -8.70 & -59.40 & 0.27 \\
\hline KIA 64 & & 27.72923 & 85.32703 & -9.05 & -59.93 & 0.18 & -8.61 & -59.80 & 0.67 \\
\hline KIA 65 & & 27.7207 & 85.32623 & -8.86 & -59.35 & 0.25 & -8.69 & -59.90 & 0.25 \\
\hline KIA 66 & & 27.72179 & 85.32652 & -8.92 & -59.55 & 0.61 & -8.70 & -59.80 & 1.03 \\
\hline KIA 67 & & 27.72462 & 85.3143 & -8.82 & -59.46 & 0.86 & -8.55 & -59.10 & 0.52 \\
\hline KIA 68 & & 27.72704 & 85.32294 & -8.77 & -59.07 & 0.92 & -8.60 & -59.20 & 0.47 \\
\hline KIA 69 & & 27.72745 & 85.32117 & -8.93 & -60.14 & 0.67 & -8.92 & -60.20 & 0.33 \\
\hline KIA 71 & Simbhanjyang (Sim.) & 27.67052 & 85.28526 & -8.95 & -63.00 & 3.32 & -8.62 & -59.20 & 1.24 \\
\hline KIA 72 & & 27.67086 & 85.28954 & -8.31 & -55.18 & 0.22 & -7.88 & -52.20 & 0.16 \\
\hline KIA 73 & & 27.66802 & 85.28635 & -7.95 & -52.91 & 0.08 & -7.88 & -51.70 & 0.16 \\
\hline KIA 74 & & 27.6705 & 85.27896 & -7.81 & -52.14 & 0.24 & -7.33 & -46.10 & 0.05 \\
\hline KIA 75 & & 27.66883 & 85.27677 & -7.92 & -52.47 & 0.14 & -7.81 & -51.90 & 0.14 \\
\hline KIA 76 & & 27.67042 & 85.27964 & -8.02 & -52.52 & 0.21 & -7.71 & -52.00 & 0.15 \\
\hline KIA 77 & & 27.6718 & 85.28361 & -8.04 & -52.09 & 0.20 & -7.37 & -47.10 & 0.28 \\
\hline KIA 78 & & 27.67322 & 85.28158 & -8.02 & -52.66 & 0.22 & -7.69 & -52.20 & 0.07 \\
\hline KIA 79 & & 27.67528 & 85.28098 & -7.94 & -52.98 & 0.03 & -7.70 & -52.70 & 0.14 \\
\hline KIA 80 & & 27.67595 & 85.28131 & -8.06 & -52.52 & 0.18 & -7.44 & -48.50 & 0.04 \\
\hline
\end{tabular}


Table 1 (continued)

\begin{tabular}{|c|c|c|c|c|c|c|c|c|c|}
\hline \multirow[t]{2}{*}{ ID } & \multirow[t]{2}{*}{ Associated supply reservoir } & \multirow[t]{2}{*}{ Northing } & \multirow[t]{2}{*}{ Easting } & \multicolumn{3}{|l|}{ Wet } & \multicolumn{3}{|l|}{ Dry } \\
\hline & & & & $\delta^{18} \mathrm{O}-\mathrm{H}_{2} \mathrm{O}$ & $\delta \mathrm{D}$ & $\mathrm{NO}_{3}-\mathrm{N}$ & $\delta^{18} \mathrm{O}-\mathrm{H}_{2} \mathrm{O}$ & $\delta \mathrm{D}$ & $\mathrm{NO}_{3}-\mathrm{N}$ \\
\hline KIA 81 & Bansbari & 27.675 & 85.42833 & -8.00 & -52.91 & 0.22 & -7.59 & -51.40 & 0.02 \\
\hline KIA 82 & & 27.67694 & 85.43528 & -8.92 & -59.84 & 0.55 & -8.92 & -63.90 & 0.27 \\
\hline KIA 83 & & 27.68083 & 85.44444 & -8.76 & -58.00 & 0.54 & -8.65 & -60.10 & 0.21 \\
\hline KIA 84 & & 27.68583 & 85.45056 & -8.77 & -58.47 & 1.12 & -8.90 & -63.00 & 0.33 \\
\hline KIA 85 & & 27.67615 & 85.4411 & -8.16 & -55.34 & 4.20 & -8.63 & -61.10 & 0.81 \\
\hline KIA 86 & & 27.67889 & 85.44472 & -8.88 & -59.45 & 0.49 & -8.90 & -62.00 & 0.31 \\
\hline KIA 87 & & 27.68889 & 85.45611 & -8.93 & -60.60 & 0.72 & -9.03 & -64.00 & 0.29 \\
\hline KIA 88 & & 27.69028 & 85.46028 & -8.80 & -59.45 & 0.36 & -8.69 & -61.60 & 0.49 \\
\hline KIA 89 & & 27.69472 & 85.46333 & -8.69 & -58.75 & 0.54 & -8.76 & -61.50 & 0.46 \\
\hline KIA 90 & & 27.69611 & 85.46566 & -8.76 & -58.70 & 0.43 & -8.98 & -63.80 & 0.22 \\
\hline
\end{tabular}

n.d. not detected

Table 2 Isotopic signatures and $\mathrm{NO}_{3}-\mathrm{N}$ data for the reservoirs (isotopic values in $\% \circ$ and $\mathrm{NO}_{3}-\mathrm{N}$ in $\mathrm{mg} \mathrm{N} / \mathrm{L}$ )

\begin{tabular}{|c|c|c|c|c|c|c|c|c|c|}
\hline \multirow[t]{2}{*}{ ID } & \multirow[t]{2}{*}{ Reservoir } & \multirow[t]{2}{*}{ Northing } & \multirow[t]{2}{*}{ Easting } & \multicolumn{3}{|l|}{ Wet } & \multicolumn{3}{|l|}{ Dry } \\
\hline & & & & $\delta^{18} \mathrm{O}-\mathrm{H}_{2} \mathrm{O}$ & $\delta \mathrm{D}$ & $\mathrm{NO}_{3}-\mathrm{N}$ & $\delta^{18} \mathrm{O}-\mathrm{H}_{2} \mathrm{O}$ & $\delta \mathrm{D}$ & $\mathrm{NO}_{3}-\mathrm{N}$ \\
\hline KIA 91 & PID & 27.72861 & 85.325 & -8.40 & -54.67 & 0.22 & -8.43 & -56.70 & 0.20 \\
\hline KIA 92 & Anamnagar & 27.70033 & 85.32589 & -8.83 & -57.44 & 0.23 & -8.30 & -55.60 & 0.16 \\
\hline KIA 93 & Bode & 27.69628 & 85.39402 & -9.08 & -64.09 & 0.21 & -9.33 & -68.00 & 0.32 \\
\hline KIA 94 & Sim & 27.67444 & 85.29222 & -8.77 & -58.57 & 0.27 & -8.85 & -60.50 & 0.27 \\
\hline KIA 95 & Bansbari & 27.68889 & 85.45667 & -7.76 & -51.37 & 0.18 & -7.56 & -51.20 & 0.08 \\
\hline KIA 96 & Sundarighat & 27.67444 & 85.30611 & -8.80 & -59.99 & 0.84 & -8.14 & -56.60 & 0.57 \\
\hline KIA 97 & Chabahil & 27.77111 & 85.35417 & -8.82 & -58.76 & 0.19 & -8.17 & -56.10 & 0.05 \\
\hline KIA 98 & Sainbu & 27.64214 & 85.30314 & -8.81 & -58.71 & 0.41 & -8.70 & -61.10 & 0.31 \\
\hline KIA 99 & Balaju & 27.73531 & 85.30086 & -8.47 & -56.61 & 0.86 & -8.09 & -54.80 & 0.51 \\
\hline
\end{tabular}

\subsection{Nitrate Concentrations of the Reservoir and Tap Water}

The $\mathrm{NO}_{3}-\mathrm{N}$ concentrations varied spatially and temporally (wet and dry seasons) (Fig. 2). $\mathrm{NO}_{3}-\mathrm{N}$ ranged from 0.03 to $8.11 \mathrm{mg} \mathrm{N} / \mathrm{L}$ during the wet season and from 0.01 to $1.88 \mathrm{mg} \mathrm{N} / \mathrm{L}$ during the dry season. The average $\mathrm{NO}_{3}-\mathrm{N}$ concentration during the wet season was higher $(0.54 \mathrm{mg} \mathrm{N} / \mathrm{L})$ than during the dry season $(0.37 \mathrm{mg} \mathrm{N} / \mathrm{L})$. Statistically, the values were found to differ significantly $(p<0.05)$ between the two seasons (Table 3 ), even though the $\mathrm{NO}_{3}-\mathrm{N}$ concentrations in some locations were similar. Similarly, the $\mathrm{NO}_{3}-\mathrm{N}$ concentrations of the reservoirs ranged from 0.18 to $0.84 \mathrm{mg} \mathrm{N} / \mathrm{L}$ during the wet season and from 0.05 to $0.57 \mathrm{mg} \mathrm{N} / \mathrm{L}$ during the dry season (Table 2). The concentrations of $\mathrm{NO}_{3}-\mathrm{N}$ in both the reservoir and tap water samples were below the permissible limit of $10 \mathrm{mg} \mathrm{N} / \mathrm{L}$ specified by both the World Health Organization (WHO) and the Nepal Drinking Water Quality Standard (NDWQS). However, Schullehner et al. (2018) suggests that when conforming with the permissible limit, the higher concentration of $\mathrm{NO}_{3}-\mathrm{N}$ during the dry season possesses risk to the water users.

In general, the water quality of the distribution tank and tap water must be identical. Although chloride $\left(\mathrm{Cl}^{-}\right)$is considered to be a major conservative tracer, $\mathrm{Cl}^{-}$was not considered in this study, as no free chlorine was measured from the samples. However, the $\mathrm{NO}_{3}-\mathrm{N}$ concentrations of the tap water and reservoir samples exhibited differences (Fig. 2). Compared with their respective reservoirs, $10 \%$ of the tap 


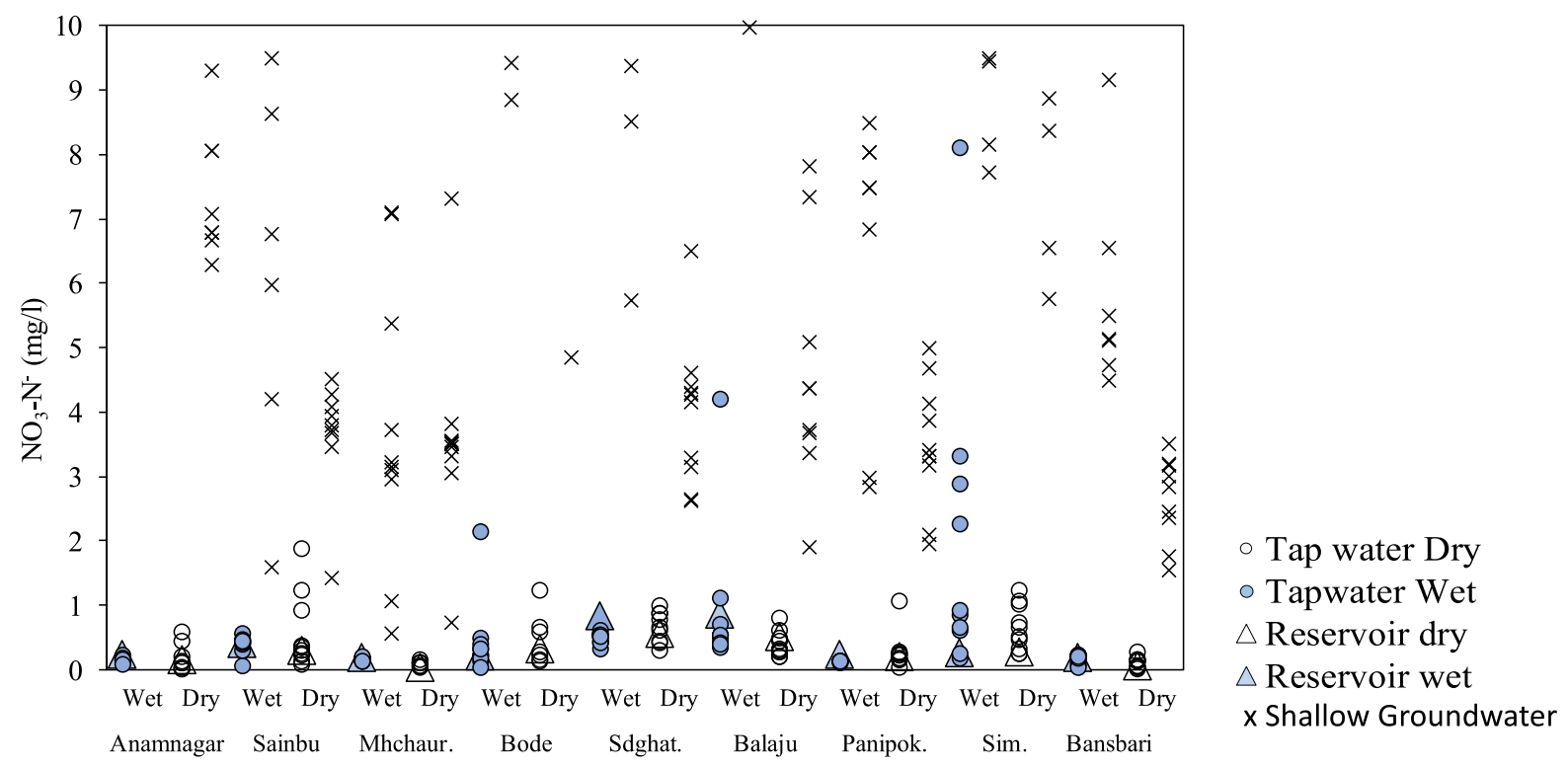

Fig. 2 Reservoir, tap water, and groundwater $\mathrm{NO}_{3}-\mathrm{N}$ concentrations. Cross mark plotted at the right of each season represents groundwater $\mathrm{NO}_{3}-\mathrm{N}(\mathrm{mg} / \mathrm{l})$ concentrations from

Table 3 Correlation matrix between $\mathrm{NO}_{3}-\mathrm{N}$ and $\delta \mathrm{D}$, and seasonal $\delta^{18} \mathrm{O}$ of tap water samples

\begin{tabular}{lccc}
\hline & $\mathrm{NO}_{3}-\mathrm{N}_{\text {wet }}$ & $\delta \mathrm{D}_{\text {dry }}$ & $\delta^{18} \mathrm{O}_{\text {dry }}$ \\
\hline $\mathrm{NO}_{3}-\mathrm{N}_{\text {wet }}$ & - & - & - \\
$\mathrm{NO}_{3}-\mathrm{N}_{\text {dry }}$ & $<0.05^{*}$ & $>0.05$ & - \\
$\delta \mathrm{D}_{\text {wet }}$ & $<0.05^{*}$ & $>0.05$ & - \\
$\delta^{18} \mathrm{O}_{\text {wet }}$ & - & - & $<0.05^{*}$ \\
\hline
\end{tabular}

*Significantly difference

water samples had higher $\mathrm{NO}_{3}-\mathrm{N}$ concentrations than the reservoirs during the wet and dry seasons, while $16 \%$ of the tap water samples had higher $\mathrm{NO}_{3}-\mathrm{N}$ concentrations during the dry season. Anamnagar (dry 2), Sainbu (dry 3), Bode (wet 1, dry 3), Sundarighat (dry 2), Balaju (wet 2, dry 1), Panipokhari (wet 1), and Simbhanjyang (wet 6 , dry 5) exhibited local contamination. Such areas of contamination are generally observed due to DNHM in IWS, while little or no contamination is observed in areas with CWS (Erickson et al., 2017, Kumpel and Nelson, 2014). In addition to DNHM, backflow and/or re-suspension of particulate matter induced by low and transient negative pressure during transfer is the governing contamination mechanism (Erickson et al., 2017; Kumpel the nearby tap water location during each consecutive season. Groundwater data are acquired from Shakya et al. (2019b)

and Nelson, 2014; van den Berg \& Danilenko, 2011). Similarly, in previous studies (Nakamura et al., 2014; Shakya et al., 2019b; Warner et al., 2008), groundwater in the $\mathrm{KV}$ was determined to be contaminated by chemical and microbiological components due to the leaky septic systems. Although a time series analysis was not performed, the shifts in $\mathrm{NO}_{3}-\mathrm{N}$ concentrations away from the reservoir and close to the groundwater indicate occurrence of various degrees of $\mathrm{NO}_{3}-\mathrm{N}$ contaminations from groundwater which is spatially varied by heterogenous anthropogenic nitrogen loading in the subsurface (Nakamura et al., 2014; Shakya et al., 2019b). As shown in Fig. 2, the deflections of tap water concentrations from those of the reservoirs were higher during the dry season, and higher $\mathrm{NO}_{3}-\mathrm{N}$ concentrations were observed during the wet season. Similar results regarding the contamination of stored piped water have been reported in the $\mathrm{KV}$ during the dry season with a larger supply gap (Shrestha et al., 2013). Although precise conclusions could not be drawn from the $\mathrm{NO}_{3}-\mathrm{N}$ concentrations alone, assumptions can be made where the increment in groundwater level and heterogeneously distributed $\mathrm{NO}_{3}-\mathrm{N}$ concentration during the wet season might have created such variations. The assumptions follow a study of India and Panama (Erickson et al., 2017), 
where the degree of intrusion was higher in areas with a lower supply, which can be used to explain the higher $\mathrm{NO}_{3}-\mathrm{N}$ deflection during the dry season in the KV. Additionally, high demand and extraction during periods of low-pressure tap water play a vital role in the intrusion (Fontanazza et al., 2015). Compared with the wet season, drinking water demand and extraction in the $\mathrm{KV}$ are higher during the dry season (KUKL, 2021), causing contamination backflow in numerous locations. However, $2 \%$ of the samples during the dry season and $7 \%$ during the wet season had $\mathrm{NO}_{3}-\mathrm{N}$ concentrations lower than those of the Sundarighat and Balaju reservoirs (Fig. 2). Such conditions wherein the tap water has lower concentrations of $\mathrm{NO}_{3}-\mathrm{N}$ than the reservoirs and lower occurrences of contamination are presumed to be caused by mixing with rainwater having lower $\mathrm{NO}_{3}-\mathrm{N}$ concentration.

\subsection{Stable Isotopes of Reservoir and Tap Water}

The $\delta \mathrm{D}$ and $\delta^{18} \mathrm{O}-\mathrm{H}_{2} \mathrm{O}$ of the tap water ranged from -66.23 to $-52.1 \%$ and from -9.48 to $-7.81 \%$, respectively, during the wet season, and ranged from -67.3 to $-46.1 \%$ ond from -9.38 to $-7.33 \%$, respectively, during the dry season. Seasonally, $\delta \mathrm{D}$ exhibited no significant changes $(>0.05)$, while $\delta^{18} \mathrm{O}$ $\mathrm{H}_{2} \mathrm{O}$ had significant variations $(<0.05)$. Similarly, the reservoir samples ranged from -64.09 to $-51.37 \%$ o and from-9.08 to $-7.76 \%$, respectively, during the wet season, and ranged from -51.2 to $-68.0 \%$ o and from-9.33 to $-7.56 \%$, respectively, during the dry season (Tables 1 and 2). The isotopic ranges were considerably higher during the dry season than during the wet season (Fig. 2). Among the service areas, Bode had the lightest isotopic values, while Bansbari had the heaviest water isotopic values during both the dry and the wet seasons. A graph of $\delta \mathrm{D}$ vs. $\delta^{18} \mathrm{O}-\mathrm{H}_{2} \mathrm{O}$ (Fig. 3) shows the spatial and temporal variations in the isotopic signatures. As reported by Wet et al. (2020), the degree of evapoconcentration or groundwater intrusion that is recharged under different climatic condition can cause variations in the tap water composition. Compared with the global (GMWL) and local (LMWL) meteoric water lines, which are defined as $\delta \mathrm{D}=8 * \delta^{18} \mathrm{O}-\mathrm{H}_{2} \mathrm{O}+10$ (Craig, 1961) and $\delta \mathrm{D}=8.1 * \delta^{18} \mathrm{O}-\mathrm{H}_{2} \mathrm{O}+12.3$ (Gajurel et al., 2006), respectively, no evidence of evaporation was observed. As the isotopic signatures of deep
Fig. 3 Plot of $\delta D$ vs. $\delta^{18} \mathrm{O}-$ $\mathrm{H}_{2} \mathrm{O}$ of the tap water and reservoir samples compared with the global meteoric water line (GMWL) (Craig, 1961) and local meteoric water line (LMWL) (Gajurel et al., 2006)

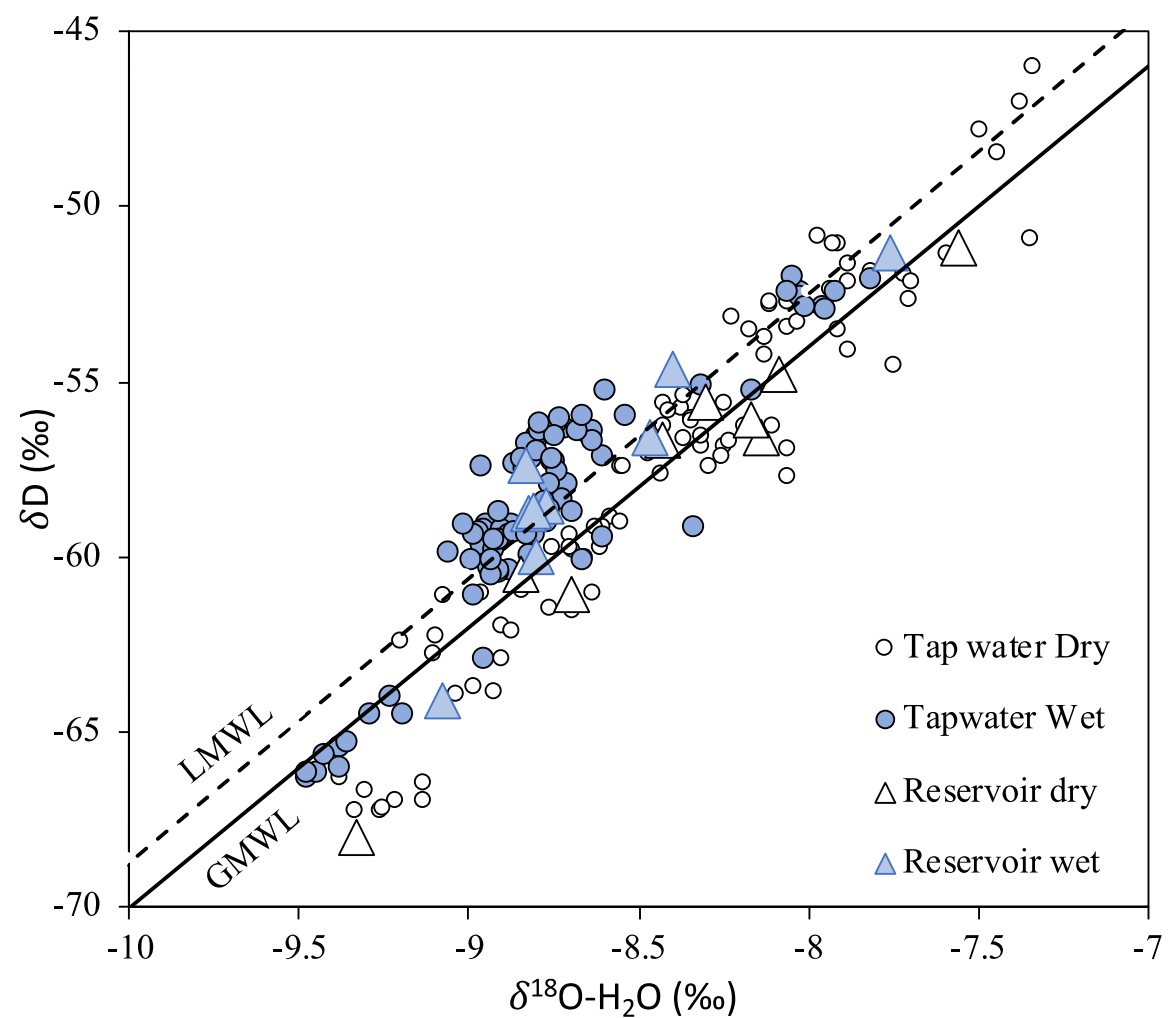


groundwater are constant throughout the entire year (Chapagain et al., 2009), cluster of the isotopic signatures from reservoirs during the wet season shows the influence of local precipitation during the pre-treatment. However, the contribution of rainfall during pre-treatment is less likely to occur. Additionally, the valley is a closed basin and no intra-basin water transport for tap water network occurred until the study was performed; the variations in the seasonal isotopic signatures are affected by spatially distributed aquifer affected by the local rainfall during the wet season. The isotopic signatures of the tap water sources varied spatially, as their sources are recharged at various altitudes (West et al., 2014; Wet et al., 2020; Zhao et al., 2017). The spatiotemporal variations therefore represent the use of isotopically distinguishable local water sources (Shakya et al., 2019a).

We also compared the $\delta \mathrm{D}$ composition of the tap water samples with that of the reservoirs and the groundwater (Fig. 4). For a threshold of 3\%o, 28\% of the isotopic values of the tap water samples were displaced away from the values of the reservoirs during the dry season, while 5\% were displaced during the wet season. Because evapoconcentration does not cause isotope fractionation, the tap water variations were likely due to groundwater contamination during the drinking water transfer. As with $\mathrm{NO}_{3}-\mathrm{N}$, the spatial isotopic distributions of the tap water sample varied with those of the on-site groundwater (Fig. 4). In addition, the tap water anomalies varied from the respective reservoirs but were similar to the respective on-site shallow groundwater isotopic signatures. Temporally, the $\delta \mathrm{D}$ values were more clustered during the wet season than the dry season The monsoon rainfall accounts for a large part of the groundwater in the KV (Prajapati et al., 2021), and the $\delta D$ values indicate the rainfall control on the tap water network in the KV.

\subsection{Comparison of $\delta \mathrm{D}$ and $\mathrm{NO}_{3}-\mathrm{N}$}

The similarities and anomalies observed in the tap water samples provide information on intrusion contamination within the tap water network. Coupled techniques have helped to determine the source and mechanism of various hydrological and hydrogeochemical processes (Umezawa et al., 2009). No significant correlations in spatial variations were observed between $\mathrm{NO}_{3}-\mathrm{N}$ and $\delta \mathrm{D}$ in the samples, a phenomenon that might be attributed to changes in the rate of transfer and nearby groundwater condition. In addition, a Pearson correlation

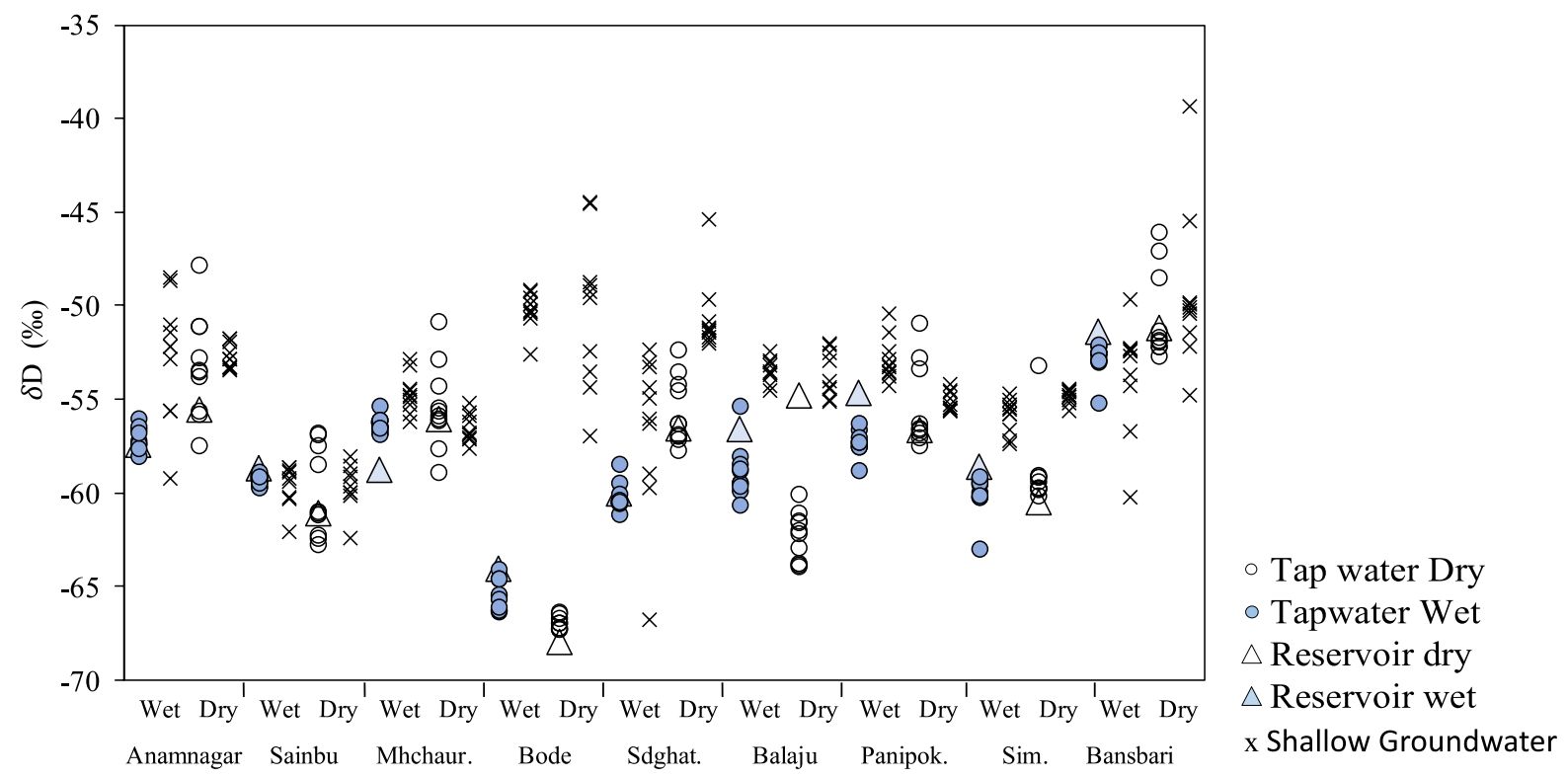

Fig. 4 Isotopic signatures of the tap water samples and those of their respective reservoirs and on-site groundwater. Cross mark plotted at the right of each season represents groundwater $\delta \mathrm{D}(\% \circ)$ concentrations from the nearby tap water location during each consecutive season. Groundwater data are acquired from Shakya et al. (2019a) 
indicates similarities between the deflected $\mathrm{NO}_{3}-\mathrm{N}$ and $\delta \mathrm{D}$ values. Although only $16 \%$ of the samples had higher $\mathrm{NO}_{3}-\mathrm{N}$ values than those of the reservoirs during the dry season, similar behaviors were observed for the variations between $\mathrm{NO}_{3}-\mathrm{N}$ versus $\delta \mathrm{D}$ and were significantly related ( $p$-value $>0.05$ ). This statistical similarity between higher $\mathrm{NO}_{3}-\mathrm{N}$ and $\delta \mathrm{D}$ values reflects intrusions from nearby groundwater sources. Comparisons of the groundwater isotopic values and those of the tap water (Fig. 4) suggest advantages in identifying possible intrusion areas. In contrast, the coherence of the $\mathrm{NO}_{3}-\mathrm{N}$ and $\delta \mathrm{D}$ values decreased to $<10 \%$ during the wet season, with no significant correlation ( $p$-value $<0.05)$. This implies the possibilities of rainfall dominated groundwater intrusions creating difficulties in disparity between groundwater and tap water from reservoirs. Uncertainty remains regarding those tap water samples with lower $\mathrm{NO}_{3}-\mathrm{N}$ values and similar $\delta \mathrm{D}$ as of the groundwater. This uncertainty may be due to the amount of rainfall infiltration and anthropogenic nitrate loading to the groundwater; however, further mixing analyses are required to confirm this. Although few of the anomalies coincided (i.e., 20 samples for both $\mathrm{NO}_{3}-\mathrm{N}$ and $\delta \mathrm{D}$ ), the obtained results indicate that $\delta \mathrm{D}$ can be used as a potential indicator in identifying the tap water leakage and groundwater intrusions.

Despite the tap water dynamics caused by the use of various water sources (Bowen et al., 2007; de Wet et al., 2020; Tipple et al., 2017; Zhao et al., 2017), the contamination from the groundwater intrusion was responsible for the variations in the isotopic signatures of the reservoirs and tap water samples. The use of coupled indicators $\mathrm{NO}_{3}-\mathrm{N}$ and $\delta \mathrm{D}$ provided a clear picture of nearby groundwater intrusions. Furthermore, comparisons of $\mathrm{NO}_{3}-\mathrm{N}$ and $\delta \mathrm{D}$ made between tap water and groundwater signal the locations of groundwater intrusions and backflow whether nearby or far from the end users within tap water network. This also helps the management to identify the areas for immediate maintenance of tap water network. Although the paper lacks information on pressure control during the water supply and water demands, due to constraints in continuous data measurement, this study presents baseline data that can be used to widen the study of tap water using stable isotopes, particularly in developing nations facing IWS.

\section{Conclusions}

Losses of the municipal supplied water through ruptures and breakages in the tap network during the high pressurized CWS is the major urban water supply issue. However, negative pressure developed during the IWS not only creates water losses but also results in contaminations due to intrusions of the groundwater through the ruptures during water transport from the reservoir to the tap. This study showcased the contamination status especially $\mathrm{NO}_{3}-\mathrm{N}$ contamination in the municipal distributed tap water and the cause of contaminations in an area facing IWS. Even when the $\mathrm{NO}_{3}-\mathrm{N}$ concentrations were within established drinking water quality standards, a comparative analysis of the tap water, reservoirs, and the surrounding groundwater indicates that up to $10 \%$ of $\mathrm{NO}_{3}-\mathrm{N}$ from tap water samples were not similar to the reservoirs during the wet season, while the same increased to $16 \%$ during the dry season. Those tap water with difference $\mathrm{NO}_{3}-\mathrm{N}$ values were found to be close to the groundwater, indicating the possibilities of intrusions. Similarly, the stable isotopic signatures of the tap water samples also varied compared with their respective reservoirs, irrespective of any fractionation caused by evaporation showing $5 \%$ variation during the wet and $28 \%$ during the dry season. The differences between wet and dry season indicates the control of the rainwater even in the tap water networks of the area with IWS. The positive correlation between $\mathrm{NO}_{3}-\mathrm{N}$ and $\delta \mathrm{D}$ indicates groundwater intrusion as one of the prime causes of water quality deterioration within the same distribution area (caused by the low or negative pressure either nearby or far from the end users). Furthermore, this study also depicts the use of $\delta \mathrm{D}$ as a possible tracer for evaluating the tap water conditions when locating the intrusions in the area with IWS.

Despite the fact that pressure control and the water supply vary depending on the distribution network and water demands, we were unable to associate pressure control information with continuous monitoring. Additionally, other conservative hydrochemical and microbiological tracers and pressure information, which can serve as strong supporting information in IWS studies, are not included due to the lack of data availability and will be including as the future task. Nevertheless, this study provided insights into the seasonal variations in $\mathrm{NO}_{3}-\mathrm{N}$ concentrations in 
the area with IWS (KV as an example) and causes of $\mathrm{NO}_{3}-\mathrm{N}$ contaminations using $\delta \mathrm{D}$ as a tracer. The tap water variations due to possible foreign water interactions and differences of $\delta \mathrm{D}$ from reservoir to the tap mentioned in this study are expected to establish the baseline in creating precise tap water studies, particularly in low-income countries.

Funding This research was carried out in the framework of the Coordinated Research Project (CRP) F33024 - "Isotope Techniques for the Evaluation of Water Sources for Domestic Supply in Urban Areas" of the International Atomic Energy Agency (IAEA), and was partly funded by Grants-in-Aid for Scientific Research (KAKENHI No. 20H02285) and Accelerating Social Implementation for SDGs Achievement (aXis: JPMJAS2005) Japan. We would also like to thank the Science and Technology Research Partnership for Sustainable Development (SATREPS), Japan International Cooperation Agency (JICA), and Japan Science and Technology (JST) for their financial support.

Data Availability The excel file of analyzed tap water data and reservoir water that supports the findings of this study are all available in repository "figshare" and cited as Shakya et al. (2021).

Data are presented in "Tap water contamination status of an intermittent water supply_.xlsx." The tap water data are presented in Table 1 while the reservoir water sample data are presented in Table 2.

\section{Code Availability Not applicable.}

\section{Declarations}

Conflict of Interest The authors declare no competing interests.

Open Access This article is licensed under a Creative Commons Attribution 4.0 International License, which permits use, sharing, adaptation, distribution and reproduction in any medium or format, as long as you give appropriate credit to the original author(s) and the source, provide a link to the Creative Commons licence, and indicate if changes were made. The images or other third party material in this article are included in the article's Creative Commons licence, unless indicated otherwise in a credit line to the material. If material is not included in the article's Creative Commons licence and your intended use is not permitted by statutory regulation or exceeds the permitted use, you will need to obtain permission directly from the copyright holder. To view a copy of this licence, visit http://creativecommons.org/licenses/by/4.0/.

\section{References}

Shakya, B., Nakamura, T., Shrestha, S., Pathak, S., Nishida, K., Malla, M. (2021).Tap water contamination status of an intermittent water supply_.xlsx. figshare. Dataset. 10.6084/m9.figshare.16584113.v1

van den Berg, C., \& Danilenko, A. (2011). The IBNET water supply and sanitation blue book: The international benchmarking network for water and sanitation utilities databook. In World Bank Publication. World Bank Group. https://openknowledge.worldbank.org/handle/10986/ 19811 (accessed on: May 2, 2021)

Bowen, G. J., Ehleringer, J. R., Chessoon, L. A., Stange, E., \& Cerling, T. E. (2007). Stable isotope ratios of tap water in the contiguous USA Gabriel. Water Resources Research, 43(3)

Chandra, S., Saxena, T., Nehra, S., \& Krishna Mohan, M. (2016). Quality assessment of supplied drinking water in Jaipur city, India, using PCR-based approach. Environ. Earth Sci., 75(2), 153. https://doi.org/10.1007/ s12665-015-4809-5

Chapagain, S., Pandey, V., Shrestha, S., Nakamura, T., \& Kazama, F. (2009). Assessment of deep groundwater quality in Kathmandu Valley using multivariate statistical techniques. Water Air and Soil Pollut., 210, 277-288. https://doi.org/10.5004/dwt.2009.492

Coelho, S. T., James, S., Sunna, N., Abu Jaish, A., \& Chatila, J. (2003). Controlling water quality in intermittent supply systems. Water Supply, 3(1-2), 119-125. https://doi.org/ 10.2166/ws.2003.0094

Craig, H. (1961). Isotopic variations in meteoric waters. Science, 133, 1702-1703. https://doi.org/10.1126/science. 133.3465.1702

de Wet, R. F., West, A. G., \& Harris, C. (2020). Seasonal variation in tap water $\delta^{2} \mathrm{H}$ and $\delta^{18} \mathrm{O}$ isotopes reveals two tap water worlds. Sci. Rep., 10(1), 13544. https://doi.org/10. 1038/s41598-020-70317-2

Dudley, N., \& Stolton, S. (2003). Running pure: The importance of forest protected areas to drinking water. https:// openknowledge.worldbank.org/handle/10986/15006

Ehleringer, J. R., Barnette, J. E., Jameel, Y., Tipple, B. J., \& Bowen, G. J. (2016). Urban water-A new frontier in isotope hydrology. Isot. Environ. Health Stud., 52(4-5), 477486. https://doi.org/10.1080/10256016.2016.1171217

Erickson, J. J., Smith, C. D., Goodridge, A., \& Nelson, K. L. (2017). Water quality effects of intermittent water supply in Arraiján, Panama. Water Res., 114, 338-350. https:// doi.org/10.1016/j.watres.2017.02.009

Fontanazza, C. M., Notaro, V., Puleo, V., Nicolosi, P., \& Freni, G. (2015). Contaminant intrusion through leaks in water distribution system: Experimental analysis. Procedia Engineering, 119(1), 426-433. https://doi.org/10.1016/j. proeng.2015.08.904

Gajurel, A. P., France-Lanord, C., Huyghe, P., Guilmette, C., \& Gurung, D. (2006). C and O isotope compositions of modern fresh-water mollusc shells and river waters from the Himalaya and Ganga plain. Chem. Geol., 233(1-2), 156-183. https://doi.org/10.1016/j.chemgeo.2006.03.002

Gonfiantini, R., Fröhlich, K., Araguás-Araguás, L., \& Rozanski, K. (1998). Isotopes in groundwater hydrology. In C. Kendal \& J. J. Mcdonnell (Eds.), Isotope Tracers in Catchment Hydrology (1998th ed., pp. 203-246). Springer International Publishing

Grimmeisen, F., Zemann, M., Goeppert, N., \& Goldscheider, N. (2016). Weekly variations of discharge and 
groundwater quality caused by intermittent water supply in an urbanized karst catchment. J. Hydrol., 537, 157-170. https://doi.org/10.1016/j.jhydrol.2016.03.045

Guragai, B., Takizawa, S., Hashimoto, T., \& Oguma, K. (2017). Effects of inequality of supply hours on consumers' coping strategies and perceptions of intermittent water supply in Kathmandu Valley. Nepal Sci. Total Environ., 599-600, 431-441. https://doi.org/10.1016/j.scitotenv.2017.04.182

Howard, G., \& Bartram, J. (2003). Domestic water quantity, service, level and health. In WHO. https://linkinghub.elsev ier.com/retrieve/pii/S000992609880189X (accessed on: June 18, 2021)

IPCC. (2008). Climate change and water: in Intergovernmental panel on climate change, 28th Session, April 9-10 (Issue 12). https://www.ipcc.ch/site/assets/uploads/2018/03/ climate-change-water-en.pdf

Jameel, Y., Brewer, S., Fiorella, R. P., Tipple, B. J., Terry, S., \& Bowen, G. J. (2018). Isotopic reconnaissance of urban water supply system dynamics. Hydrol. Earth Syst. Sci., 22(11), 6109-6125. https://doi.org/10.5194/ hess-22-6109-2018

Koju, N. K., Prasai, T., Shrestha, S. M., \& Raut, P. (2015). Drinking water quality of Kathmandu Valley. Nepal J. Sci. Technol., 15(1), 115-120. https://doi.org/10.3126/njst. v15i1.12027

KUKL. (2019). Land acquisition and involuntary resettlement due diligence report. Kathmandu Upatyaka Khanepani Limited, Ministry Water Supply, Govt. of Nepal for the Asian Development Bank. Package No: KUKL/ DNI/W/02/21 and KUKL/DNI/W/02/22

KUKL. (2021). Kathmandu Upatyaka Khanepani Limited: Annual report-tenth anniversary, Kathmandu

Kumpel, E., \& Nelson, K. L. (2014). Mechanisms affecting water quality in an intermittent piped water supply. Environ. Sci. Technol., 48(5), 2766-2775. https://doi.org/10. 1021/es405054u

Lambert, A., Charalambous, B., Fantozzi, M., Kovac, J., Rizzo, A., \& Galea St. John, S. (2014). 14 years experience of using IWA best practice water balance and water loss performance indicators in Europe. Proceedings of the WaterLoss Conference 2014, May, 1-31

Liu, G., Zhang, Y., Knibbe, W.-J., Feng, C., Liu, W., Medema, G., \& van der Meer, W. (2017). Potential impacts of changing supply-water quality on drinking water distribution: A review. Water Res., 116, 135-148. https://doi.org/ 10.1016/j.watres.2017.03.031

McIntosh, A. C. (2003). Asian water supplies: Reaching the urban poor. IWA Publishing.

Nakamura, T., Nishida, K., Kazama, F., Osaka, K., Chapagain, K., \& S. (2014). Nitrogen contamination of shallow groundwater in Katmandu Valley. Nepal J. Jpn. Assoc. Hydrol. Sci., 44(4), 197-206. https://doi.org/10.4145/jahs. 44.197

Nakamura, T., Nishida, K., \& Kazama, F. (2016). Influence of a dual monsoon system and two sources of groundwater recharge on Kofu basin alluvial fans. Japan Hydrol. Res., 48(4), 1071-1087. https://doi.org/10.2166/nh.2016.208

Nakamura, T., Chapagain, S. K., Pandey, V. P., Osada, K., Nishida, K., Malla, S. S., \& Kazama, F. (2012). Shallow groundwater recharge altitude in the Kathmandu Valley. In Sangam Shrestha, D. Pradhananga, \& V. P. Pandey
(Eds.), Kathmandu Valley Groundwater Outlook (pp. 39-45). Asian Institute of Technology (AIT), The Small Earth Nepal (SEN), Center of Research for Environmet Energy and Water (CREEW), International Research Centre for River Basin Environment - University of Yamanashi (ICRE-UY)

Prajapati, R., Upadhyay, S., Talchabhadel, R., Thapa, B. R., Ertis, B., Silwal, P., \& Davids, J. C. (2021). Investigating the nexus of groundwater levels, rainfall and land-use in the Kathmandu Valley. Nepal Groundw. Sustain. Dev., 14, 100584. https://doi.org/10.1016/j.gsd.2021.100584

Schullehner, J., Hansen, B., Thygesen, M., Pedersen, C.B., Sigsgaard, T. (2018). Nitrate in the drinking water and colorectral cancer risk: A nationwide population-based cohort study. Cancer Epidemology, 143.https://doi.org/10. 1002/ijc. 31306

Shakya, B. M., Nakamura, T., Kamei, T., Shrestha, S. D., \& Nishida, K. (2019a). Seasonal groundwater quality status and nitrogen contamination in the shallow aquifer system of the Kathmandu valley. Nepal Water, 11(10), 2184. https://doi.org/10.3390/w11102184

Shakya, B. M., Nakamura, T., Shrestha, S. D., \& Nishida, K. (2019b). Identifying the deep groundwater recharge processes in an intermountain basin using the hydrogeochemical and water isotope characteristics. Hydrol. Res., 50(5), 1216-1229. https://doi.org/10.2166/nh.2019.164

Shrestha, S., Malla, S. S., Aihara, Y., Kondo, N., \& Nishida, K. (2013). Water quality at supply source and point of use in the Kathmandu Valley. J. Water Environ. Technol., 11(4), 331-340. https://doi.org/10.2965/jwet.2013.331

Shrestha, S., Nakamura, T., Malla, R., \& Nishida, K. (2014). Seasonal variation in the microbial quality of shallow groundwater in the Kathmandu Valley. Nepal Water Sci. Technol. Water Supply, 14(3), 390. https://doi.org/10. 2166/ws.2013.213

Shrestha, S., Aihara, Y., Bhattrai, A. P., Bista, N., Rajbhandari, S., Kondo, N., Kazama, F., Nishida, K., \& Shindo, J. (2017). Dynamics of domestic water consumtpion in the urban area of the Kathmandu Valley: Situation analysis pre and post 2015 Gorkha earthquake. Water, 9, 222. https://doi.org/10.3390/w9030222

Thapa, B. R., Ishidaira, H., Pandey, V. P., \& Shakya, N. M. (2017). A multi-model approach for analyzing water balance dynamics in Kathmandu Valley. Nepal J. Hydrol. Reg. Stud., 9, 149-162. https://doi.org/10.1016/j.ejrh. 2016.12.080

Thapa, K., Shrestha, S. M., Rawal, D. S., \& Pant, B. R. (2019). Quality of drinking water in Kathmandu valley. Nepal Sustain. Water Resour. Manag., 5(4), 1995-2000. https:// doi.org/10.1007/s40899-019-00354-X

Tipple, B. J., Jameel, Y., Chau, T. H., Mancuso, C. J., Bowen, G. J., Dufour, A., Chesson, L. A., \& Ehleringer, J. R. (2017). Stable hydrogen and oxygen isotopes of tap water reveal structure of the San Francisco Bay Area's water system and adjustments during a major drought. Water Res., 119, 212-224. https://doi.org/10.1016/j.watres.2017. 04.022

Udmale, P., Ishidaira, H., Thapa, B., \& Shakya, N. (2016). The status of domestic water demand: Supply deficit in the Kathmandu Valley. Nepal Water, 8(5), 196. https://doi. org/10.3390/w8050196 
Umezawa, Y., Hosono, T., Onodera, S., Siringan, F., Buapeng, S., Delinom, R., Yoshimizu, C., Tayasu, I., Nagata, T., \& Taniguchi, M. (2009). Erratum to "Sources of nitrate and ammonium contamination in groundwater under developing Asian megacities." Sci. Total Environ., 407(9), 32193231. https://doi.org/10.1016/j.scitotenv.2009.01.048

Warner, N. R., Levy, J., Harpp, K., \& Farruggia, F. (2008). Drinking water quality in Nepal's Kathmandu Valley: A survey and assessment of selected controlling site characteristics. Hydrogeol. J., 16(2), 321-334. https://doi.org/10. 1007/s10040-007-0238-1

West, A. G., February, E. C., \& Bowen, G. J. (2014). Spatial analysis of hydrogen and oxygen stable isotopes ("isoscapes") in ground water and tap water across South Africa. J. Geochem. Explor., 145, 213-222. https://doi. org/10.1016/j.gexplo.2014.06.009

WHO \& UNICEF. (2000). Global water supply and sanitation assessment 2000 report annex A: methodology. In WHO/ UNICEF.https://doi.org/10.1016/0273-1177(96)00073-7

Wols, B. A., van Daal, K., \& van Thienen, P. (2014). Effects of climate change on drinking water distribution network integrity: Predicting pipe failure resulting from differential soil settlement. Procedia Eng., 70, 1726-1734. https://doi. org/10.1016/j.proeng.2014.02.190

Yang, L., Song, X., Zhang, Y., Han, D., Zhang, B., \& Long, D. (2012). Characterizing interactions between surface water and groundwater in the Jialu River basin using major ion chemistry and stable isotopes. Hydrol. Earth Syst. Sci., 16(11), 4265-4277. https://doi.org/10.5194/ hess-16-4265-2012

Zhao, S., Hu, H., Tian, F., Tie, Q., Wang, L., Liu, Y., \& Shi, C. (2017). Divergence of stable isotopes in tap water across China. Scientific Reports, 7, 1-14. https://doi.org/10.1038/ srep43653

Publisher's Note Springer Nature remains neutral with regard to jurisdictional claims in published maps and institutional affiliations. 